\title{
PERHITUNGAN BIAYA NORMAL PROGRAM PENSIUN USIA NORMAL DENGAN METODE ENTRY AGE NORMAL (PERCENT DOLLAR)
}

\author{
Fia Fridayanti Adam ${ }^{1}$ \\ ${ }^{\prime}$ Tenaga Pengajar Program Studi Administrasi Asuransi dan Aktuaria Program Vokasi UI
}

\begin{abstract}
Abstrak - Setiap orang yang bekerja akan menerima upah dari hasil kerjanya. Selama bekerja, setiap pekerja berhak mendapatkan perlindungan dari perusahaan (atau pemberi kerja) dari berbagai risiko yang mungkin terjadi, termasuk risiko menjadi tua. Risiko tersebut dapat dihindari ataupun dikurangi dengan mengikutsertakan pekerja pada program pensiun baik yang dikelola oleh perusahaan atau pun ikut dengan kesadaran sendiri.

Program pensiun terbagi atas program pensiun iuran pasti dan program pensiun manfaat pasti. Penelitian ini akan menggunakan program pensiun manfaat pasti. Ada beberapa metode yang digunakan untuk menghitung dana pensiun manfaat pasti. Diantaranya adalah metode Unit Credit, metode Aggregate cost, Entry Age Normal, Benefit Prorate dan lainnya. Penelitian ini menggunakan metode Entry Age Normal, yaitu perhitungan program pensiun yang menggunakan asumsi perhitungan aktuaria pada saat peserta mulai bekerja. Data yang digunakan adalah data dari para dosen tetap Program Vokasi UI dimana rentang usianya bervariasi dan tanggal mulai bekerja cenderung sama. Hasil perhitungan berupa Biaya Normal dan Kewajiban Aktuaria.
\end{abstract}

Kata Kunci: Program Pensiun, manfaat, Entry Age Normal, biaya normal, kewajiban aktuaria.

\section{PENDAHULUAN}

Setiap orang yang bekerja akan menerima upah dari hasil kerjanya. Selama bekerja, setiap pekerja berhak mendapatkan perlindungan dari perusahaan (atau pemberi kerja) dari berbagai risiko yang mungkin terjadi, termasuk risiko menjadi tua. Risiko tersebut dapat dihindari ataupun dikurangi dengan mengikutsertakan pekerja pada program pensiun baik yang dikelola oleh perusahaan atau pun ikut dengan kesadaran sendiri.

Program pensiun terbagi atas program pensiun iuran pasti dan program pensiun manfaat pasti. Program pensiun iuran pasti adalah program pensiun yang iurannya ditetapkan dalam peraturan dana pensiun dan seluruh iuran serta hasil pengembangannya dibukukan pada rekening masing-masing peserta sebagai manfaat pensiun, sedangkan program pensiun manfaat pasti adalah program pensiun yang manfaatnya ditetapkan dalam peraturan dana pensiun.

Di Indonesia, penetapan usia pensiun dibedakan atas usia pensiun normal dan usia pensiun dipercepat. Kebanyakan pemberi kerja menetapkan usia 56 sebagai batasan usia pensiun normal. Sedangkan dalam dunia pendidikan, usia pensiun normal yang ditetapkan bagi tenaga pendidik adalah 65 tahun. Sedangkan yang dimaksud usia pensiun dipercepat adalah usia pensiun yang belum memenuhi usia pensiun normal tetapi 
boleh diajukan. Biasanya ada persyaratan minimal masa kerja dan usia yang dibolehkan untuk mengajukan pensiun.

Penelitian ini akan menggunakan program pensiun manfaat pasti. Ada beberapa metode yang digunakan untuk menghitung dana pensiun manfaat pasti. Diantaranya adalah metode Unit Credit, metode Aggregate cost, Entry Age Normal, Benefit Prorate dan lainnya. Metode Benefit Prorate terbagi atas Constant Dollar dan Constant Percent of Salary. Benefit Prorate Constant Dollar dapat digunakan dalam perhitungan dana pensiun tanpa menggunakan besarnya gaji peserta program pensiun selama kerja, sedangkan metode Constant Percent of Salary menggunakan besarnya gaji.

Penelitian Indriani et. al (1) menghitung dana pensiun usia normal dengan menggunakan metode Benefit Prorate Constant Dollar. Hasilnya menunjukkan bahwa walaupun tanpa asumsi gaji, semakin besar usia seseorang masuk program pensiun maka semakin besar iuran yang harus dibayarkan. Penelitian tersebut menggunakan asumsi aktuaria berdasarkan table Mortalita 1999. Serupa dengan Benefit Prorate, metode Entry Age Normal juga terbagi dua yaitu Constant Dollar dan Percent Dollar. Hanya saja pada metode Entry Age Normal perhitungan dimulai pada saat seseorang mulai masuk kerja di perusahaan, bukan hanya pada saat dia terdaftar pada program pensiun.Penelitian ini menggunakan metode Entry Age Normal dengan asumsi tabel mortalita yang digunakan adalah table Mortalita 2012.
Selain itu, penelitian ini juga menggunakan asumsi aktuaria sebagai berikut:

- Tingkat suku bunga yang berlaku tetap sebesar $7 \%$ per tahun

- Tingkat kenaikan gaji tetap sebesar $5 \%$ per tahun

- Usia pensiun normal adalah 65 tahun

- Tidak ada peserta yang keluar, cacat, atau meninggal selama ikut program pensiun

Dalam perhitungan dana pensiun, keluaran yang timbul adalah Biaya Normal dan Kewajiban Aktuaria. Biaya Normal per tahun adalah nilai aktuaria dari sebagian manfaat pensiun total yang mengacu pada tahun valuasi, dengan asumsi valuasi pada saat awal tahun. Biaya Normal ini serupa dengan iuran yang harus dibayarkan. Sedangkan kewajiban aktuaria adalah kewajiban Dana Pensiun yang dihitung berdasarkan anggapan bahwa Dana Pensiun terus berlangsung sampai terpenuhinya seluruh kewajiban kepada peserta dan pihak yang berhak. Penelitian ini hanya akan menghitung biaya normal.

Dengan menggunakan data penggajian tenaga pendidik tetap Program Vokasi UI, penelitian ini bertujuan :

1. Menghitung biaya normal program pensiun dengan metode Entry Age Normal Percent Dollar

2. Menganalisis biaya normal program pensiun normal dari tenaga pendidik tetap Program Vokasi UI. 
Adapun sistematika penelitian ini adalah:

1. Pengambilan data peserta program pensiun dari tenaga pendidik tetap Program Vokasi UI kemudian data yang diperoleh diklasifikasikan berdasarkan usia pada saat masuk bekerja dan usia pensiun serta data demografi lainnya.

2. Menghitung dan menyajikan data keseluruhan terkait dasar kesejahteraan atau gaji pokok BHMN/Pegawai Program Vokasi UI beban fakultas, proyeksi gaji pada saat 1 tahun sebelum pensiun, manfaat, Nilai Tunai manfaat pada saat masuk, biaya normal pada saat masuk, dan biaya normal pada saat valuasi, berdasarkan asumsi-asumsi aktuaria yang ditetapkan dengan metode Entry Age Normal

\section{ANALISIS DAN PEMBAHASAN}

Data dalam penelitian ini adalah data Staf pengajar yang diambil dari data para pendidik tetap Program Vokasi UI.. Data ini berisi usia masuk dan usia pensiun peserta program dana pensiun. Data yang diambil adalah peserta program pensiun dengan usia masuk dari 28 sampai 52 tahun sejak periode 2011. Penelitian ini menganalisa data diantaranya dengan menyajikan data demografi. Data demografi staf pendidik tetap, selanjutnya disebut sebagai peserta, dapat dilihat dalam Tabel 1 berikut:
Tabel 1.

Data Demografi

\begin{tabular}{l|l|c}
\hline \multicolumn{1}{c}{ Variabel } & \multicolumn{1}{c}{ Kategori } & Persentase \\
\hline Jenis Kelamin & Laki-Laki & $45 \%$ \\
\hline & Perempuan & $55 \%$ \\
\hline Usia & $28-33$ & $34 \%$ \\
\hline & $34-39$ & $54 \%$ \\
\hline & $43-48$ & $7 \%$ \\
\hline Status & $51-54$ & $5 \%$ \\
Kepegawaian & BHMN & $100 \%$ \\
\hline $\begin{array}{l}\text { Jumlah Data } \\
\text { Responden (N) }\end{array}$ & & $0 \%$ \\
\hline
\end{tabular}

Dengan melihat Tabel $1 \mathrm{di}$ atas, terlihat bahwa masa kerja dari para peserta secara umum masih panjang. Oleh karena para peserta tersebut kebanyakan masuk kerja pada tahun yang sama,yaitu tahun 2011, maka besaran gaji pokok juga relatif sama. Hanya 2 orang yang berbeda, 1 orang masih sarjana dan 1 orang lagi baru masuk di tahun 2013.

Proyeksi kenaikan gaji diambil $5 \%$ dengan alasan tingkat inflasi nasional yang sekitar ... dan dengan asumsi ideal replacement rate $70 \%$ maka besarnya manfaat yang akan diterima oleh para peserta sangat bervariasi tergantung dari lamanya masa kerja peserta. Secara deskriptif dapat dilihat dari Tabel 2 berikut:

Tabel 2.

Nilai Manfaat pada usia 65 tahun (dalam Rp)

\begin{tabular}{|l|l|}
\hline Mean & 63.956 .970 \\
\hline Median & 64.602 .093 \\
\hline Modus & 76.609 .022 \\
\hline Minimum & 28.873 .135 \\
\hline Maksimum & 93.118 .745 \\
\hline
\end{tabular}


Dari Tabel 2 tersebut, terlihat bahwa dari besarnya gaji pokok yang relatif sama, yaitu per bulan, akan menghasilkan jangkauan manfaat yang cukup jauh. Hal ini terjadi karena usia masuk dari para peserta yang cukup bervariasi sehingga bila peserta akan pensiun pada usia yang sama, maka masa kerja dari para peserta juga akan bervariasi. Akibatnya adalah besarnya manfaat yang akan diterima oleh peserta juga akan bervariasi. Untuk lebih jelasnya, dapat dilihat dalam Gambar 1 berikut:

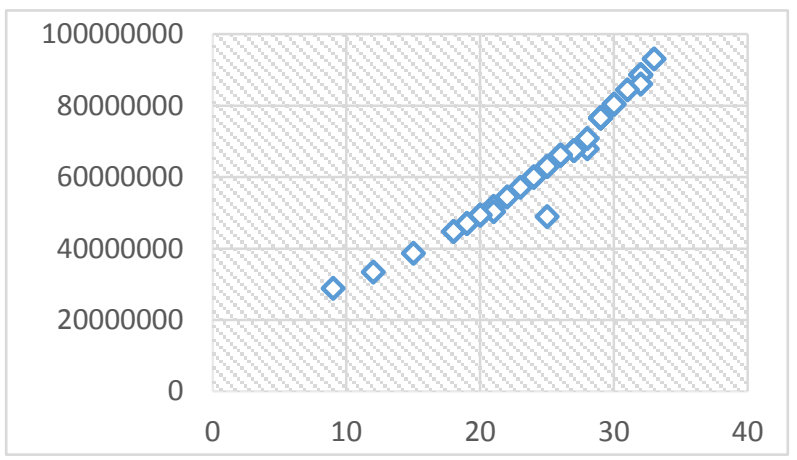

\section{Gambar 1}

Besar Manfaat pada usia 65 tahun

Dari Gambar 1 di atas menceritakan manfaat yang akan diterima pada usia pensiun, yaitu usia 65 tahun. Terlihat bahwa semakin lama masa kerja seseorang maka semakin besar manfaat yang akan diperolehnya. Manfaat yang kecil akan diterima oleh peserta yang mulai bekerja pada usia yang cukup tua, dengan demikian peserta tersebut mempunyai masa kerja yang pendek. Besar manfaat yang berkumpul di rentang 45000000-90000000 terjadi karena rentang usia peserta $88 \%$ berada di antara 28-39 tahun.
Untuk mendapatkan manfaat yang besarnya seperti digambarkan dalam Gambar 1 dan Tabel 2, maka Dana Pensiun harus menghitung Biaya Normal. Biaya Normal per tahun adalah nilai aktuaria dari sebagian manfaat pensiun total yang mengacu pada tahun valuasi, dengan asumsi valuasi pada saat awal tahun. Biaya Normal ini serupa dengan iuran yang harus dibayarkan.

Dengan metode Entry Age Normal, setiap peserta diasumsikan telah menjadi peserta program pensiun ketika pertama kali dipekerjakan atau segera setelah memenuhi syarat. Pada saat masuk tersebut nilai tunai dari semua biaya normal sama dengan nilai tunai manfaat pensiun.

$$
N C_{e} \ddot{a}_{e: r-e}^{s}=U S_{e} \ddot{a}_{e: r-e}^{s}=B_{r} \frac{D_{r}^{(\tau)}}{D_{e}^{(\tau)}} \ddot{a}_{r}^{(12)}
$$

dimana

$N C_{e}=$ biaya normal pada saat masuk

$\ddot{a}_{e: r-e}^{s}=$ anuitas berdasarkan gaji selama masa kerja

$U=$ persentasi

$S_{e}=$ gaji pada saat masuk

$B_{r}=$ Manfaat pada saat pensiun

$D_{r}^{(\tau)}=$ faktor decrement total pada saat usia pensiun, penurunan populasi karena meninggal, keluar, cacat, atau waktunya pensiun

$D_{e}^{(\tau)}=$ faktor decrement total pada saat usia masuk

Persamaan di sebelah kanan adalah nilai tunai manfaat yang akan diterima peserta pada saat pensiun yang dihitung pada saat peserta mulai bekerja. Persamaan di sebelah 
kiri adalah nilai tunai dari biaya normal yang dihitung pada saat masuk kerja. Sedangkan persamaan yang di tengah menunjukkan bahwa biaya normal merupakan persentasi dari gaji yang naik setiap tahun.

Perhitungan anuitas dan faktor decrement dilakukan dengan asumsi tingkat suku bunga sebesar $7 \%$ per tahun fixed selama perhitungan. Walaupun tingkat suku bunga selalu berubah-ubah setiap tahunnya, asumsi fixed ini dilakukan hanya untuk memudahkan saja. Sedangkan $7 \%$ diambil dengan alasan tidak terlalu jauh dengan tingkat inflasi RI saat ini.

Tabel Mortalitas yang digunakan adalah Tabel Mortalita Indonesia (TMI) 2012 dengan alasan TMI 2012 adalah tabel mortalita terbaru yang ada saat ini.

Metode Entry Age Normal akan menghitung biaya normal pada saat peserta mulai masuk kerja. Perhitungan tidak dimulai pada saat seseorang mulai bergabung ke Dana Pensiun. Dalam penelitian ini, deskripsi biaya normal dari para peserta dapat dilihat dalam Tabel 3 berikut:

Tabel 3.

Biaya Normal per tahun pada saat masuk

\begin{tabular}{|l|l|}
\hline Mean & 3016589.276 \\
\hline Median & 2612950.077 \\
\hline Modus & 2127387.927 \\
\hline Minimum & 1872943.823 \\
\hline Maksimum & 8033571.159 \\
\hline
\end{tabular}

Nilai minimum biaya normal yaitu sebesar Rp 1.872.943,823 dibebankan bagi peserta tertua dengan masa kerja 33 tahun. Sedangkan biaya normal tertinggi, yaitu Rp. 8.033.571.159 dibebankan pada peserta dengan masa kerja tersingkat.

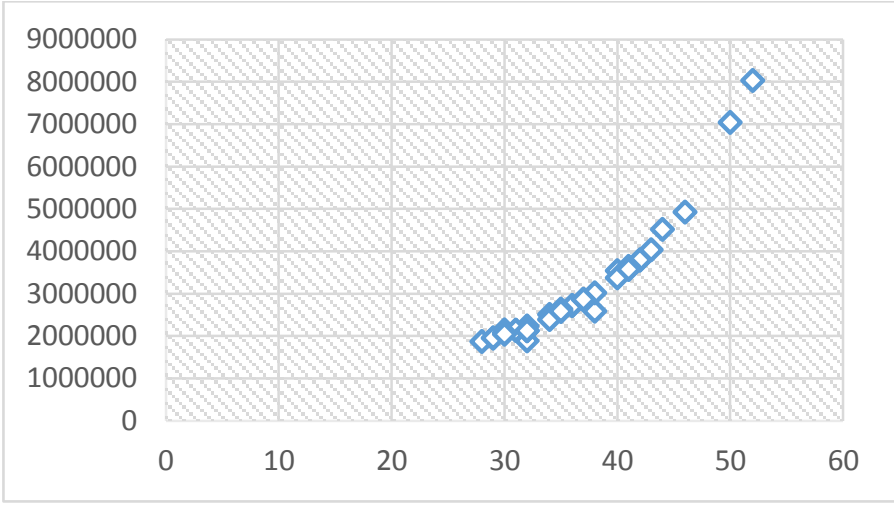

Gambar 2.

Biaya Normal per tahun pada saat masuk.

Gambar 2 menunjukkan semakin tua seseorang mulai bekerja maka biaya normal yang harus dibayarkan oleh peserta tersebut akan semakin besar. Atau, semakin pendek masa kerja dari para peserta maka semakin besar biaya normal yang harus ditanggung.

Hal yang sama terjadi bila perhitungan dilakukan pada saat valuasi, yaitu pada akhir 2013. Biaya normal yang didapat pada saat valuasi lebih besar bila dibandingkan dengan pada saat masuk. Pola yang sama juga terjadi. Semakin panjang masa kerja maka semakin kecil biaya normal. 


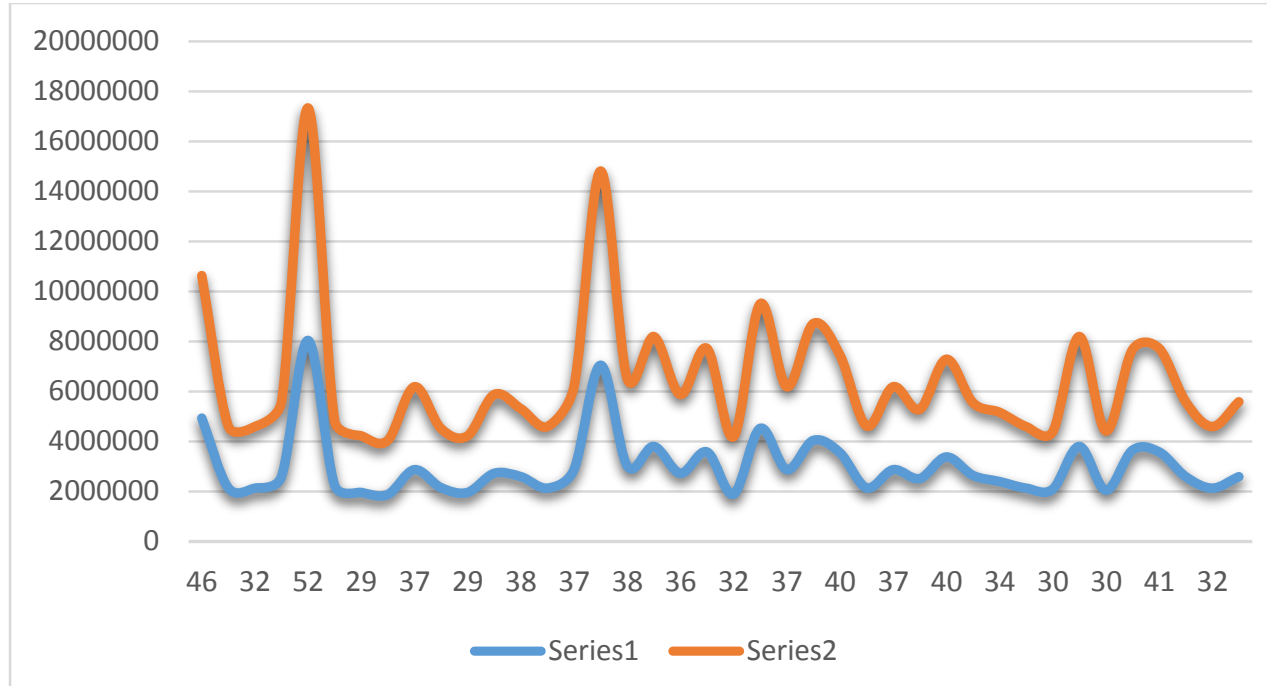

Gambar 3.

Biaya normal pada saat valuasi dan saat masuk

Hasil perhitungan biaya normal pada saat valuasi dapat dilihat dalam Tabel 4 berikut:

Tabel 4.

Biaya Normal pada saat valuasi

\begin{tabular}{|l|l|}
\hline & Biaya Normal \\
\hline Mean & 3449077 \\
\hline Median & 2995384 \\
\hline Modus & 2462717 \\
\hline Minimum & 2168167 \\
& \\
\hline Maksimum & 9299863 \\
\hline
\end{tabular}

\section{KESIMPULAN}

Program dana pensiun adalah program yang memberikan pembayaran sejumlah uang tertentu atas digunakan untuk menghitung dana pensiun dengan asumsi pensiun normal. Perhitungan dana pensiun digunakan untuk mendapatkan manfaat pensiun dan iuran pensiun.

Metode Entry Age Normal (EAN) merupakan salah satu metode untuk menghitung pendanaan pensiun. Metode EAN berasumsi setiap peserta telah menjadi peserta program pensiun ketika pertama kali dipekerjakan atau segera setelah memenuhi syarat. Perhitungan dana pensiun menghasilkan biaya normal dengan asumsiasumsi aktuaria yang ditetapkan di awal. Perhitungan program dana pensiun menunjukkan bahwa usia masuk kerja dan masuk program dana pensiun mempengaruhi manfaat pensiun dan biaya normal

Hasil penelitian ini menunjukkan bahwa semakin lama masa kerja seseorang maka semakin besar manfaat yang akan diperoleh. Untuk mendapatkan manfaat yang telah ditetapkan tersebut, hasil juga menunjukkan semakin lama masa kerja peserta maka semakin kecil biaya normal. 


\section{DAFTAR PUSTAKA}

Aitkens, W. 1996. A Problem-solving Approach to Pension Funding and Valuation. Actex Publication.

Bowers,N.L, Gerber, H.U., Hickman, J.C., Jones, D.A., dan Nesbitt, C.J.(1997). Actuarial Mathematics The Society of Actuaries. Illinois.

Gerber, H. U. 1997. Life Insurance Mathematics. 3 nd ed. Springer Verlag. Berlin

Grimmet, G. R. and D. R. Stirzaker . 2001. Probability and Random Processes. 3nd ed .University Press. Oxford. New York.

Indriani, Y, Alwine, D, Munarsih, E. 2009. Perhitungan Dana Pensiun untuk Pensiun Normal Berdasarkan Metode Constant Dollar; Studi Kasus: PT Taspen Palembang. Jurnal Penelitian Sains Volume 12 No 2(A). Palembang

Jordan, C.W. (1991). Society of Actuaries' Textbook On Life Contingencies . The Sanjaya, K.D.,Permana, F.J., dan Kristiani , F . (2011). "Perhitungan Nilai - Nilai Aktuaria Dengan Asumsi Tingkat Suku Bunga Berubah Secara Stokastik” Mat Stat. 11. 2. 152.

\section{Sumber lainnya:}

Keputusan Menteri Keuangan Republik Indonesia No.510/KMK.06/2002, Pendanaan dan Solvabilitas Dana Pensiun.Menteri Keuangan Republik Indonesia, Jakarta

Keputusan Menteri Keuangan Republik Indonesia No. 511/KMK.06/2002. Investasi Dana Pensiun. Menteri Keuangan Republik Indonesia, Jakarta

Tabel Mortalita Taspen 2012

Undang-undang Republik Indonesia No 11 tahun 1992 tentang Dana Pensiun. 